The Open Civil Engineering Journal
CrossMark
Content list available at: www.benthamopen.com/TOCIEJ/
DOI: $10.2174 / 1874149501610010782$

RESEARCH ARTICLE

\title{
Utilization of High Calcium Content Fly Ash: Flexural Strength of Geopolymer Concrete Beams in Sea Water Environment
}

\author{
Ridho Bayuaji*, M Sigit Darmawan, Boedi Wibowo, NA Husin and Srie Subekti \\ Institut Teknologi Sepuluh Nopember, Civil Engineering Department, Surabaya, Indonesia
}

Received: January 17, 2016

Revised: September 09, 2016

Accepted: September 09, 2016

\begin{abstract}
This paper presents a study of the flexural strength of geopolymer concrete beam using high calcium content fly ash (FA) in marine environment, without high heat curing. Two series of beam specimens were loaded to failure to study the effect of chloride environment on the flexural strength of geopolymer concrete beams. Series I specimens were subjected to sea environment, whereas series II were kept at room temperature. Tests performed on concrete cylinders show that the sea water has no effect on compressive and splitting tensile stress of high calcium content FA based geopolymer concrete. However, the ratio of splitting and compressive strength for both series was approximately $44 \%$, almost double than that of normal concrete. In addition, the flexural test of concrete beams shows that the average cracking load for series I specimens was $275 \%$ higher than that of series II. However, the ultimate load, crack pattern and deflection characteristic for both series were very similar.
\end{abstract}

Keywords: Beam, Flexural strength, Fly ash, Geopolymer, Marine environment.

\section{INTRODUCTION}

Considerable research has been conducted on geopolymer concrete during the last two decades [1 - 4] on its properties and application on structural material [5]. The objective of this research is to find a more environmentally friendly, durable and sustainable material for construction industry. Geopolymer concrete thus far seen as a promising alternative to ordinary concrete [6]. However, the research on fly ash (FA) geopolymer [7 - 9] has been mainly focused on the utilization of low calcium content FA [10]. Very limited research work dealt with the use of high calcium content FA for geopolymer concrete, known as class C FA [11]. In some countries such as Indonesia, class C FA is more abundant than that of low calcium FA [7]. Further, most of the work used high heat curing to obtain the design compressive strength. The use of high heat curing will adds significant cost in the production of geopolymer concrete if this method is going to be used in practice. Chloride ingress so far was seen as a main threat to service life of concrete structures in marine environment. Based on this argument, the main objective of this study is to provide more understanding of the behavior of geopolymer concrete beams under flexural load using high calcium content FA without high heat curing and subjected to chloride attack. To obtain more realistic results, concrete beams will be subjected to sea water environment by immersing test specimens in sea splash zone area. Further, concrete beams will be loaded to failure under flexural action.

\section{EXPERIMENTAL DETAILS}

\subsection{Specimens Details}

Two series of concrete beams were used in this study to investigate the strength of geopolymer concrete beams (GCB) under pure bending:

i. Series I - beams cured in sea water at splashing zone

* Address correspondence to this author at the Institut Teknologi Sepuluh Nopember, Civil Engineering Department, Surabaya, Indonesia; Tel/Fax: +62315938025; E-mail: bayuaji@ce.its.ac.id 
ii. Series II - beams cured in room temperature

The two series used concrete beams with a length of $1500 \mathrm{~mm}$ and $100 \times 150 \mathrm{~mm}$ in cross section. The longitudinal reinforcement was $8 \mathrm{~mm}$ in diameter (grade 240), while the shear reinforcement was $6 \mathrm{~mm}$ in diameter (grade 240). Each series comprised of three beams. Series I consists of B1, B2 and B3, while series II consists of B4, B5 and B6. All the beams, which had similar reinforcement detail were designed to fail in pure flexure. The geometry of the beam can be seen in Fig. (1).

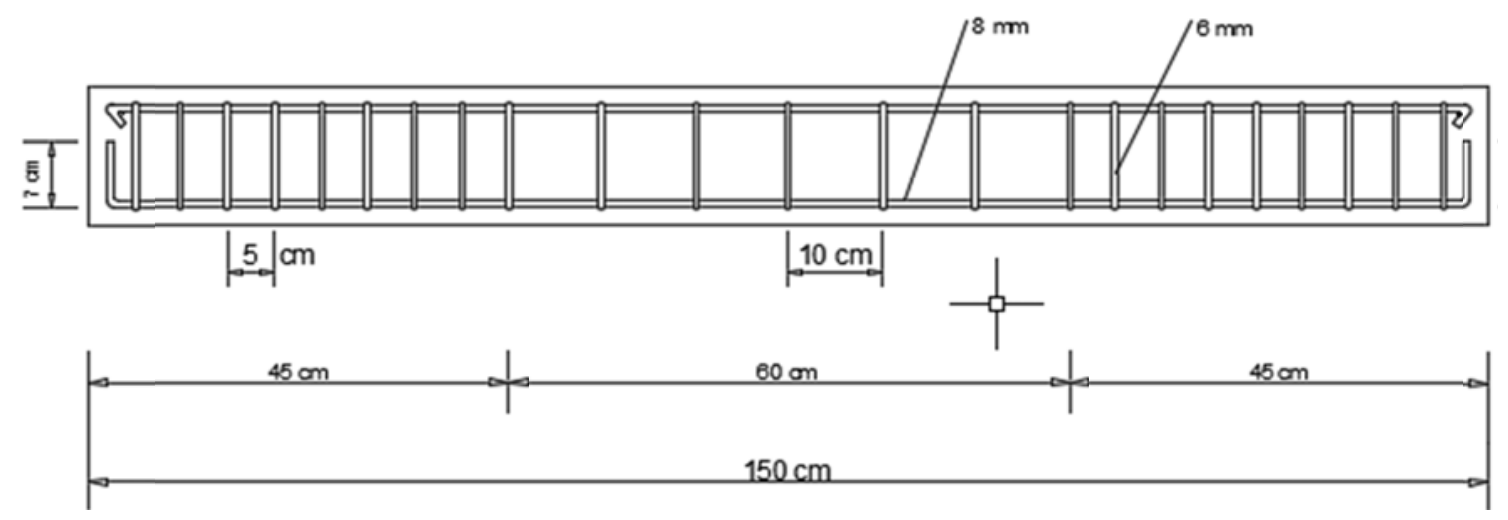

Fig. (1). Specimen detail.

\subsection{Materials}

FA available from local power plant at Paiton East Java Indonesia was used for all tests. Chemical composition of FA determined from X-Ray Fluorescence (XRF) is given in Table 1. This table shows that the CaO content of the FA is around $10.69 \%$ by weight. Therefore, based on ASTM C618-08 this FA can be classified as type C. High CaO content nowaday, is more common for FA obtained from local power plant in Indonesia. This high content of CaO may pose a problem during mixing due to high risk of fast setting. Note that for FA type F, the maximum limit of $\mathrm{CaO}$ content is $10 \%$.

Table 1. Chemical composition of FA.

\begin{tabular}{|c|c|}
\hline Oxides & Weight (\%) \\
\hline $\mathrm{SiO}_{2}$ & 41.97 \\
$\mathrm{Al}_{2} \mathrm{O}_{3}$ & 15.55 \\
$\mathrm{CaO}$ & 14.15 \\
$\mathrm{MgO}$ & 6.19 \\
$\mathrm{Na}$ & 2.26 \\
$\mathrm{~K}_{2} \mathrm{O}$ & 1.73 \\
$\mathrm{TiO}_{2}$ & 0.87 \\
$\mathrm{Fe}_{2} \mathrm{O}_{3}$ & 14.16 \\
$\mathrm{SO}_{3}$ & 2.12 \\
$\mathrm{P}_{2} \mathrm{O}_{5}$ & 0.22 \\
$\mathrm{MnO}$ & 0.12 \\
$\mathrm{SrO}$ & 0.65 \\
\hline $\mathrm{Total}$ & 100.00 \\
\hline
\end{tabular}

Currently, the mix design of geopolymer concrete is still being studied. In this study, the mix design was taken from previous study using Taguchi method. In this method, all parameters that have significant effects on the strength of geopolymer concrete were considered, while the number of experiment was kept minimum [12]. The design experiment method used was the Taguchi method with orthogonal array, L9 $\left(3^{4}\right)$ to run at once four variables. Binder/aggregate ratio, alkaline/FA ratio, superplasticizier (SP) percentage and curing method were considered as the four variables having significant effects on the compressive strength.

The design compressive strength was $25 \mathrm{MPa}$. The geopolymer concrete mixture used is given in Table 2. Previous study showed that the type of FA greatly influenced the quality of geopolymer binder. FA type, especially its chemical composition, depends on power plant operation method [13 - 15]. Due to extensive use of coal a alternative source energy of oil and gas during the last decade in Indonesia, high quality (high calories) coal is becoming scarce and 
difficult to find. As a result, low quality coal (low calories) is more often used for power plant operation. The FA produced from this coal is not as good quality as usually found before. Based on available data, type F FA in Indonesia is very difficult to obtain and type C FA is nowadays more commonly found [12]. In this study, the FA used is 504 $\mathrm{kg} / \mathrm{m}^{3}$ to achieve the design strength of $25 \mathrm{MPa}$.

Table 2. Geopolymer concrete mixture.

\begin{tabular}{|c|c|}
\hline Material & Quantity \\
\hline Fly ash $\left(\mathrm{kg} / \mathrm{m}^{3}\right)$ & 504 \\
\hline Coarse aggregate $\left(\mathrm{kg} / \mathrm{m}^{3}\right)$ & 1008 \\
\hline Fine aggregate $\left(\mathrm{kg} / \mathrm{m}^{3}\right)$ & 672 \\
\hline $\mathrm{NaOH} 14 \mathrm{M}$ & 86.4 \\
\hline $\mathrm{Na}_{2} \mathrm{SiO}_{3}$ & 123.2 \\
\hline Superplasticizer & 15.2 \\
\hline $\mathrm{Added}$ water & 10.08 \\
\hline $\mathrm{Na}_{2} \mathrm{SiO}_{3}: \mathrm{NaOH}$ & 1.43 \\
\hline
\end{tabular}

Fine aggregate used for GCB was natural river sand, whereas coarse aggregate used was a crushed stone with maximum size of $20 \mathrm{~mm}$. The properties of coarse aggregate and fine are given in Tables 3 and 4 . SP used was Conplast SP425 produced by Fosroc. From previous study, this superplasticizer has special characteristic to extend the setting time of geopolymer binder [16]. Thus, the main purpose of using SP in the mixture is not only for improving the workability, but potentially to extend the setting time.

Table 3. Properties of coarse aggregate (crushed stone).

\begin{tabular}{|c|c|c|c|}
\hline Sieve size (mm) & Mass retained on each sieve (gram) & Mass retained on each sieve (\%) & Cumulative mass retained on each sieve (\%) \\
\hline 4.76 & 4.00 & 0.80 & 0.80 \\
\hline 2.38 & 8.50 & 1.70 & 2.50 \\
\hline 1.19 & 41.00 & 8.20 & 10.70 \\
\hline 0.59 & 124.5 & 24.90 & 35.60 \\
\hline 0.297 & 168 & 33.60 & 69.20 \\
\hline 0.149 & 112 & 22.40 & 91.60 \\
\hline Pan & 42 & 8.40 & 100 \\
\hline Total & 500 & $100 \%$ & \\
\hline & Fineness modulus $=2.10 ;$ Specific gravity $(\mathrm{SSD})=2.69 ;$ Bulk density $(\mathrm{SSD})=1.63 ;$ Water absorption=0.75\% \\
\hline
\end{tabular}

Table 4. Properties of fine aggregate (river sand).

\begin{tabular}{|c|c|c|c|}
\hline Sieve size (mm) & Mass retained on each sieve (gram) & Mass retained on each sieve (\%) & Cumulative mass retained on each sieve (\%) \\
\hline $11 / 2{ }^{\prime}$ & 0 & $0 \%$ & $0 \%$ \\
\hline $3 / 4 ”$ & 7215 & $45.09 \%$ & $45.09 \%$ \\
\hline $3 / 8 ”$ & 7755 & $48.47 \%$ & $93.56 \%$ \\
\hline 4.76 & 984.5 & $6.15 \%$ & $99.71 \%$ \\
\hline 2.38 & 15.0 & $0.09 \%$ & $99.80 \%$ \\
\hline 1.19 & 1.7 & $0.01 \%$ & $99.81 \%$ \\
\hline 0.59 & 2.5 & $0.02 \%$ & $99.83 \%$ \\
\hline 0.297 & 2.5 & $0.02 \%$ & $99.85 \%$ \\
\hline 0.149 & 9.5 & $0.06 \%$ & $99.91 \%$ \\
\hline 0 & 14.3 & $0.09 \%$ & $100.00 \%$ \\
\hline Total & 16000 & $100.00 \%$ & \\
\hline & Fineness modulus $=8.38 ;$ Specific gravity (SSD) $=2.58 ;$ Bulk density (SSD) $=1.37 ;$ Water absorption $=3.98 \%$ \\
\hline
\end{tabular}

The compressive and splitting tensile strength of geopolymer concrete at the time of test was determined from concrete cylinders of dimension $100 \times 200 \mathrm{~mm}$. For each series of test, the average value of three cylinder samples was used as concrete and splitting tensile strength. All cylinders were cured in the same condition as the concrete beams. The reinforcing bars were tensile tested to determine its yield strength. Three reinforcing bars $(6 \mathrm{~mm}$ and $8 \mathrm{~mm})$ were tested to determine their yield strength. The result of tensile test of rebar was given in Tables $\mathbf{5}$ and $\mathbf{6}$. These tables show 
that the yield strength of rebar varied between 463.99 $\mathrm{MPa}$ and 523.24 MPa. These values are higher than the design yield strength of $240 \mathrm{MPa}$ for plain bar. To determine theoretical value flexural capacity of GCB, the average value of yield strength of $480.81 \mathrm{MPa}$ was used. Note that the average ultimate strength of this rebar was $643.50 \mathrm{MPa}$.

Table 5. Yield strength of rebar $(6 \mathrm{~mm})$.

\begin{tabular}{|c|c|c|c|}
\hline Sample & Diameter $(\mathbf{m m})$ & Yield strength $\left(\mathbf{f}_{\mathbf{y}}\right) \mathbf{M P a}$ & Ultimate strength $\left(\mathbf{f}_{\mathbf{u}}\right)$ MPa \\
\hline 1 & 6.43 & 523.24 & 661.74 \\
\hline 2 & 6.45 & 489.45 & 627.10 \\
\hline 3 & 6.42 & 494.13 & 633.11 \\
\hline \multicolumn{2}{|c|}{ Average } & 502.27 & 640.65 \\
\hline
\end{tabular}

Table 6. Yield strength of rebar $(8 \mathrm{~mm})$.

\begin{tabular}{|c|c|c|c|}
\hline Sample & Diameter $(\mathbf{m m})$ & Yield strength $\left(\mathbf{f}_{\mathbf{y}}\right) \mathbf{M P a}$ & Ultimate strength $\left(\mathbf{f}_{\mathbf{u}}\right)$ MPa \\
\hline 1 & 7.57 & 488.56 & 644.02 \\
\hline 2 & 7.56 & 489.87 & 645.74 \\
\hline 3 & 7.59 & 463.99 & 640.74 \\
\hline \multicolumn{2}{|c|}{ Average } & 480.81 & 643.50 \\
\hline
\end{tabular}

\subsection{Mixing and Curing}

Geopolymer concrete was mixed according to the conventional procedure used in the production of portland cement concrete. $\mathrm{NaOH}$ and sodium silicate solution were prepared separately and mixed together at the time of casting. Note that $\mathrm{NaOH}$ solution was prepared a day earlier before casting to avoid heat generation when $\mathrm{NaOH}$ flake reacts with water. FA and fine aggregate were first mixed together in a dry state for 5 minutes using electric mixer. Then, coarse aggregate was added to the FA and the fine aggregate until the coarse aggregate was uniformly distributed in concrete batch. Finally, the alkaline solution with superplasticizer was added and the entire batch was mixed for 5 minutes.

Fig. (2) shows the resulted geopolymer concrete after mixing. Slump test after concrete mixing gave $140 \mathrm{~mm}$ of slump. The concrete flowed and tended to segregate between coarse and fine aggregate. However, the concrete became very sticky after 30 minutes from mixing. This condition was expected since FA used in the mixture has a high CaO content. For field and mass application, this fast setting needs to be resolved for future application of geopolymer concrete using type C of FA. Fig. (3) shows twelve concrete cylinders used for compression and splitting tensile test. Six cylinders were then cured in sea water at splashing zone area for series I and the rest were cured in room temperature for series II.

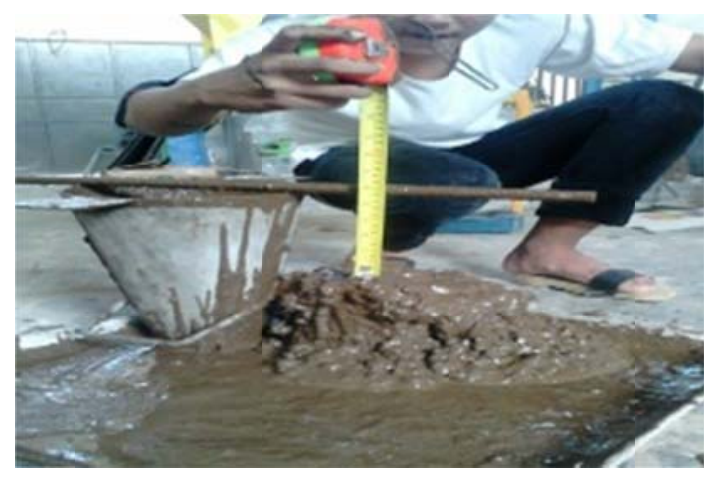

Fig. (2). Slump test for geopolymer concrete.

After casting, the beams were left for 24 hours and then removed from wood molding. All specimens were then cured for 28 days in the designated environment. Room temperature during the test was kept between $30-32^{\circ} \mathrm{C}$ for series II test. The beams for series I were transported to seashore at Suramadu Bridge Surabaya and placed in a splashing zone area. This series was designed to experience cycles of wet and drying due to tide cycles. The specimens for series II were allowed to dry for 2 days before loading to failure. Fig. (4) shows the beams after being removed from molding, 
whereas Fig. (5) shows the beams after being cured for 28 days at sea water. Fig. (5) shows that the surface of the beams changes to whitish appearance due to chlorides deposit. The previous study [17] showed that the chloride penetration and corrosion of embedded steel decreased with the high $\mathrm{Na}(\mathrm{OH})$ concentration. In this study, $\mathrm{Na}(\mathrm{OH})$ used was 14 molar and therefore chloride penetration to the concrete beam will be restricted and the chlorides are deposited on the concrete surfaces.

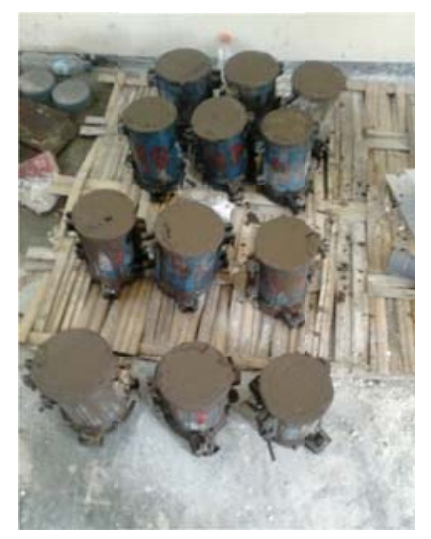

Fig. (3). Concrete cylinders for compression and tensile strength test.

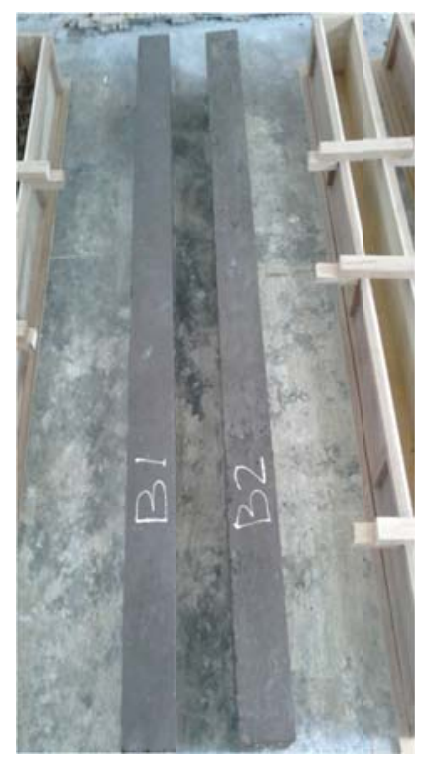

Fig. (4). Geopolymer concrete beam after 2 days of casting.

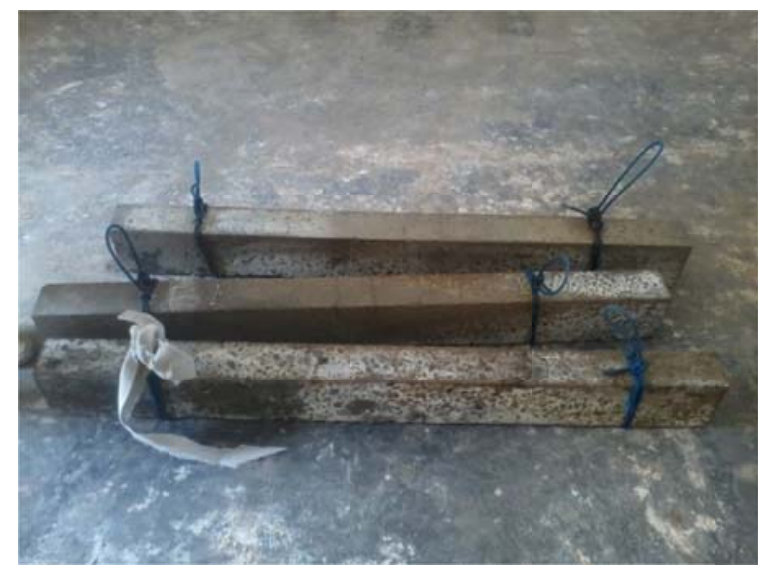

Fig. (5). Geopolymer concrete beam after cured for 28 days in sea water. 


\subsection{Testing Procedure}

The beams tested simply supported over a span of $1300 \mathrm{~mm}$ in a $1000 \mathrm{kN}$ hydraulic test rig and loaded with two symmetrical point loads, see (Fig. 6). The distance between the applied loads was $600 \mathrm{~mm}$ and applied on two points each $300 \mathrm{~mm}$ away from the middle of the beam toward the support. To produce flexural failure in the middle span, stirrups at shear span were spaced closer than that required to support the design ultimate load. At each load increment the vertical deflection of the beam was measured by two dial gauges and one Linier Variable Displacement Transducer (LVDT), see (Fig. 7). The dial gauge was installed below the applied load whereas the LVDT was installed in the center of the beam. The average of these three readings was used as the displacement of GCB. Data logger was used to record the vertical displacement and the corresponding load during the test. Visual observations of the cracks were made during the test. At each load increment, the beam was carefully inspected and all cracks and their corresponding loads were marked. The mode of failure of the beams was also recorded.

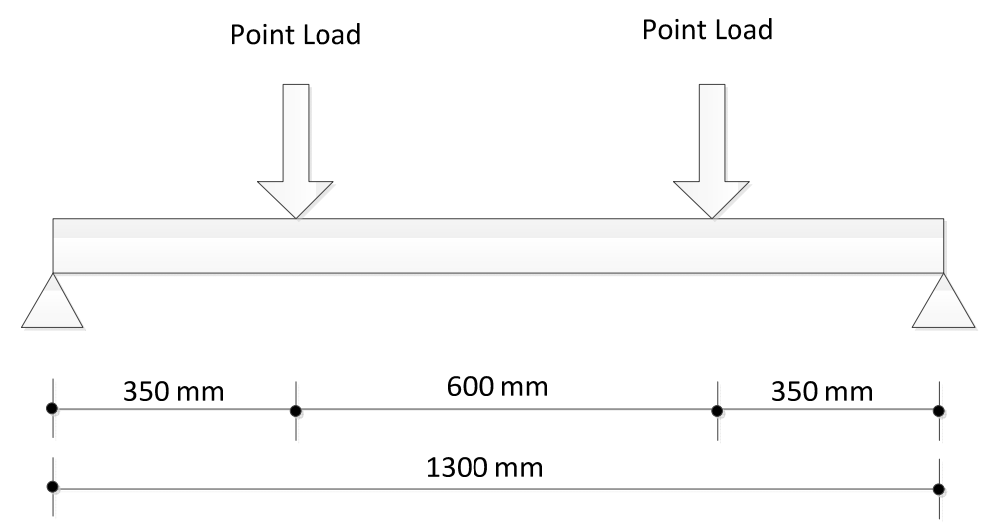

Fig. (6). The modelling of setting load.

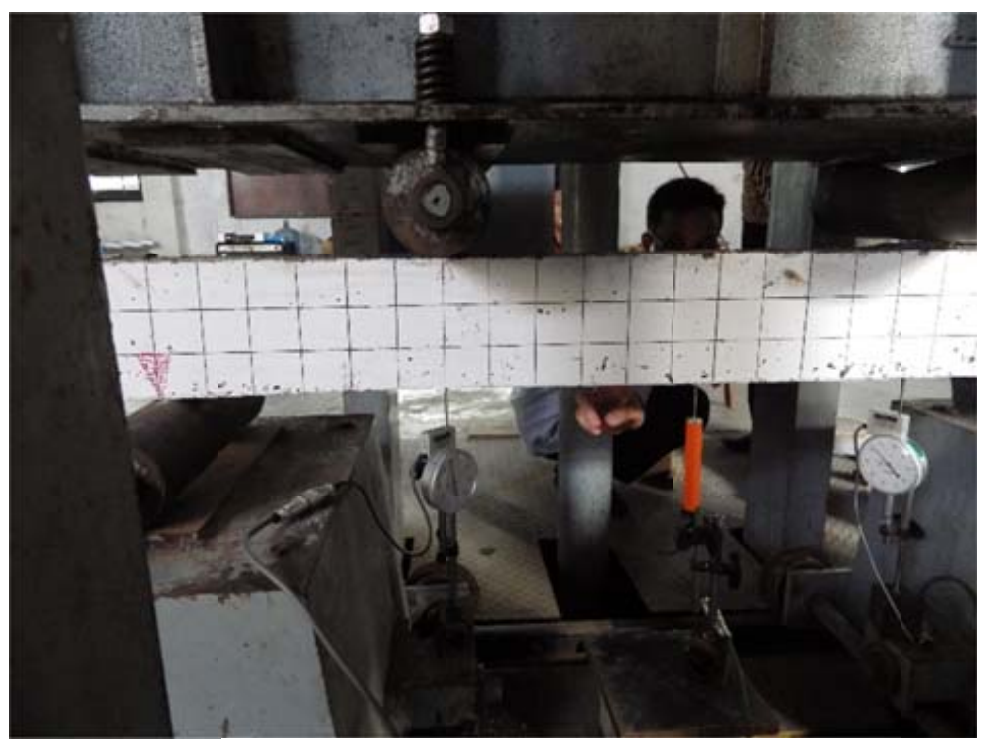

Fig. (7). Loading test arrangement.

\section{RESULTS AND DISCUSSION}

\subsection{Compressive and Splitting Tensile Strength of Concrete}

Compressive and splitting tensile strength of concrete cylinder of series I and II tests is given in Table 7. This table shows that the average compressive and splitting tensile strength of the two series test are very close to one another. 
This result shows that the sea water environment (series I) has relatively no effect on compressive and splitting tensile strength of GCB [18]. However, the compressive strength of series I test has a slightly lower strength variation than series II test. This is rather surprising considering that the nature of environment at splashing zone area is subjected to continuous changes. The highest compressive strength of $16.927 \mathrm{MPa}$ was achieved for sample B6. Overall, the compressive strength of concrete cylinder did not reach the design strength of $25 \mathrm{MPa}$. The main factor that may contribute to these lower strength is possibly the absence of high heat curing during the tests. However, previous study showed that high calcium reduces mechanical properties of geopolymer cured at elevated temperatures [19]. Further, using of heat cure will add significant cost in the production of geopolymer concrete, if practiced. Thus, in this study only room temperature was used. Fast setting of mixture during placing of concrete prevented proper compaction and thus lead to lower concrete compressive, strength. Higher dispersion of test resuts is possibly caused by the presence of FA. FA is a waste material and therefore it has a very high variation in terms of its composition. Table 7 also indicates that the splitting tensile strength of geopolymer concrete is reasonably high if compared with its compressive strength. The splitting tensile strength is around $44 \%$ of its compressive strength. For non geopolymer concrete the splitting tensile strength is generally no more than $20 \%$ of its compressive strength.

Table 7. Compressive and splitting tensile strength of geopolymer concrete.

\begin{tabular}{|c|c|c|c|c|c|}
\hline Sample & Series & Compressive strength (MPa) & Average & Splitting tensile strength (MPa) & Average \\
\hline B1 & \multirow{3}{*}{ I } & 13.745 & \multirow{3}{*}{14.339} & 5.8 & \multirow{3}{*}{6.40} \\
\hline $\mathrm{B} 2$ & & 13.873 & & 6.5 & \\
\hline B3 & & 15.400 & & 6.9 & \\
\hline B4 & \multirow{3}{*}{ II } & 14.382 & \multirow{3}{*}{14.297} & 5.7 & \multirow{3}{*}{6.37} \\
\hline B5 & & 11.582 & & 6.9 & \\
\hline B6 & & 16.927 & & 6.5 & \\
\hline
\end{tabular}

\subsection{Crack Development and Mode of Failure}

The early stages of loading the beams were almost free from cracks, especially series I test. Flexural (vertical) cracks first developed in the region of higher moment (middle span). With increasing load, additional bending cracks were formed throughout the middle span. At the same time, the existing cracks lengthened and widened. In the shear span region, almost no cracks were formed. This showed that the designed shear reinforcement worked very well to prevent shear failure. Figs. (8 and 9) showed the crack pattern of series I and II tests, respectively. Both figures show that the crack pattern of the two series was very similar.

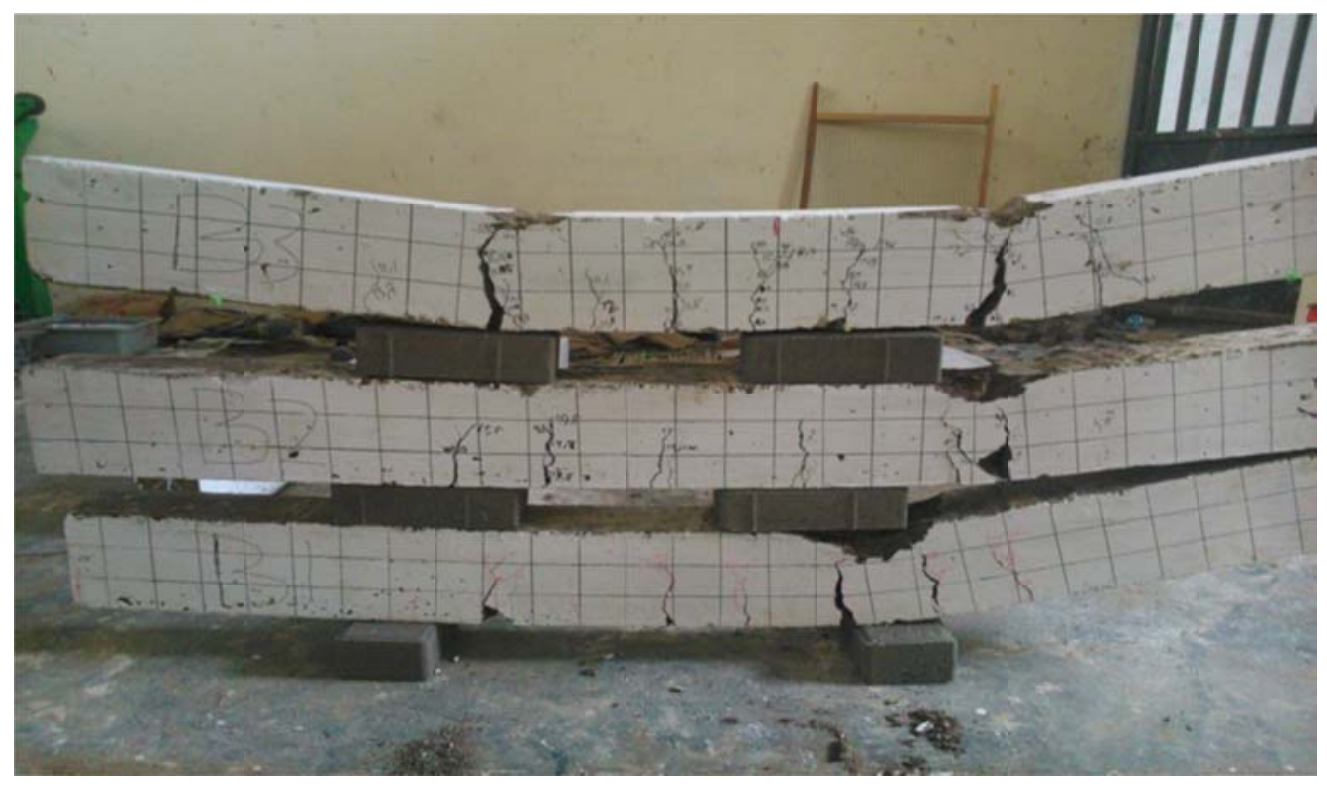

Fig. (8). Crack pattern of series I test (B1, B2 and B3). 


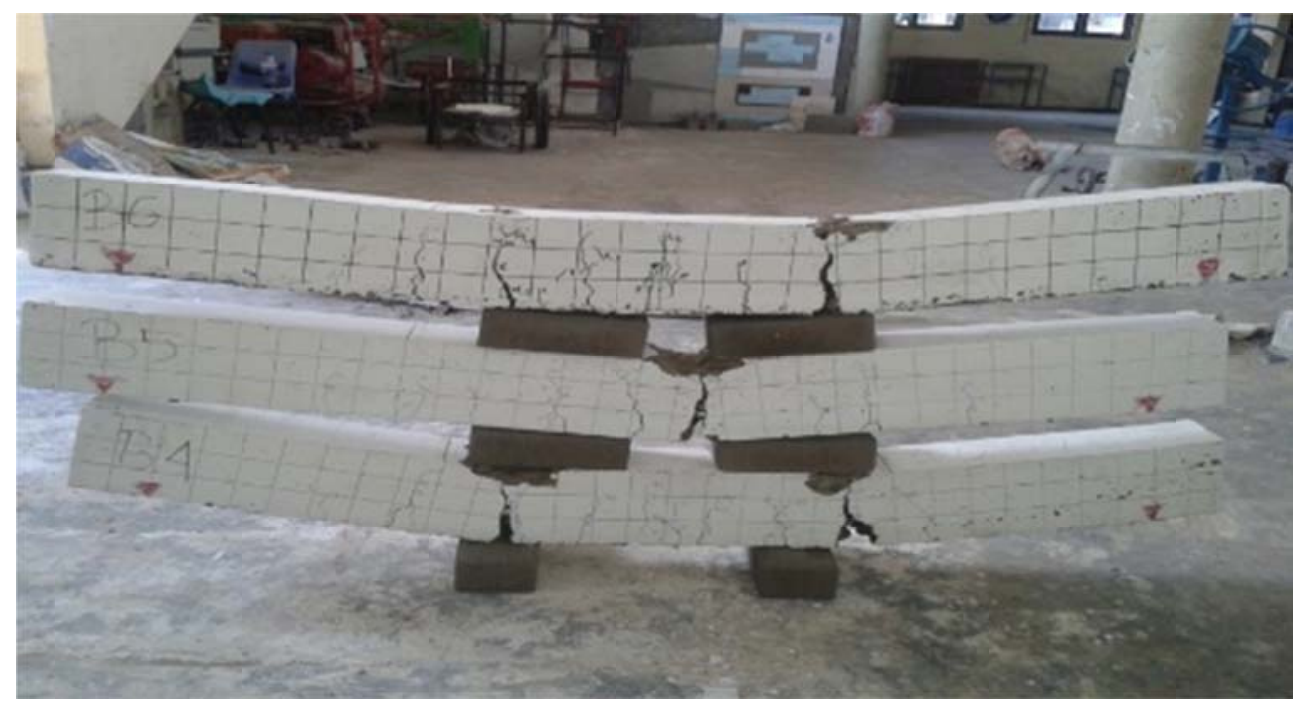

Fig. (9). Crack pattern of series II test.

Fig. (8) shows that after loading to failure specimen B1 had fewer cracks than specimen B2 and B3. This specimen has recorded the highest ultimate load. Crack that leads to failure at series I formed directly below the applied load. However, B1 has less developed cracks in midspan region as it has failed by rather sudden failure of concrete directly under the applied load. This type of failure may be caused by improper compaction of concrete in this region due to shear reinforcement spaced at closer distance than that of midspan region. A very similar trend was found in series II test, where specimen B4 had the highest ultimate load and also had fewer cracks than specimens B5 and B6, seen in Fig. (9). However, in contrast to the other specimens B5 failed due to crack formed in the middle of span.

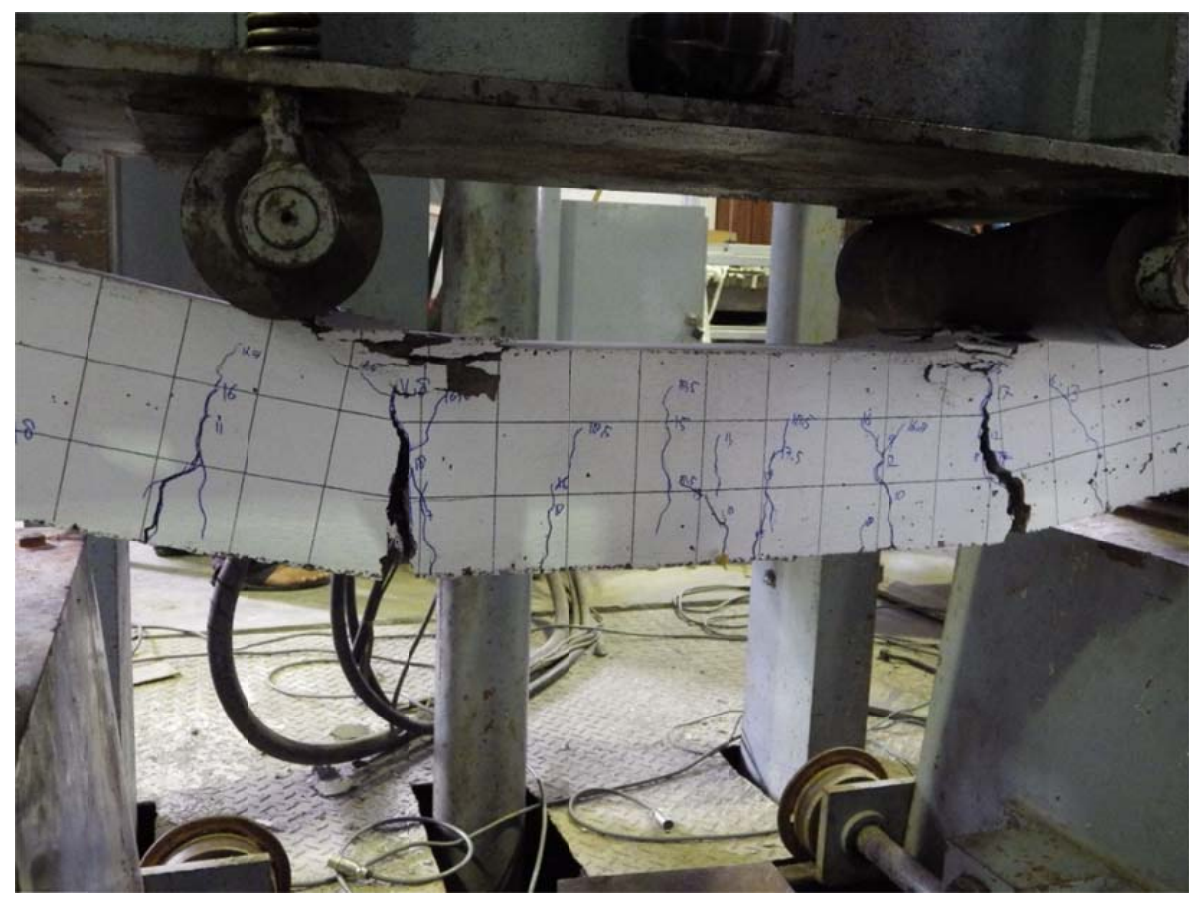

Fig. (10). Yielding of rebar and crushing of compressive zone at ultimate load.

The two series of tests showed that the beams were failed due to flexural action. Vertical cracks that lead to failure formed in the middle span, mostly directly under the applied load. The failure of the beams were relatively ductile and initiated by yielding of the steel and followed by crushing of concrete compression zone, seen in Fig. (10). There was no indication of bond failure and splitting of concrete along the tensile reinforcing bar. Examination of the rebar after the loading test of series I beams showed no sign of corrosion after 28 days of sea exposure. 


\subsection{Load Deflection Characteristic}

Load deflection characteristic of GCB was recorded using data logger. To avoid possible damage of LVDT due to unexpected failure mode of GCB, LVDT was removed from the first two loading tests before ultimate load reached. Note that the first two beams loaded to failure was specimend B1 and B2. As the first two loading tests showed a relatively ductile mode of failure of GCB and showed no indication of sudden failure of the beam, LVDT was fully installed up to the failure load in the subsequence tests.

The load deflection for all specimens is presented in Fig. (11). This figure shows that the load deflection for the two series of tests appears to be very similar up to $1300 \mathrm{~kg}$. However, specimens B1 and B2 appear to have higher stiffness than the other specimen, see (Fig. 12). These two specimens also have the highest load. However, it was rather unfortunate that LVDT was removed before ultimate load reached for these two specimens. Fig. (12) shows the stiffness degradation curve for all beams. During loading tests, all the beams followed almost similar strength degradation curves.

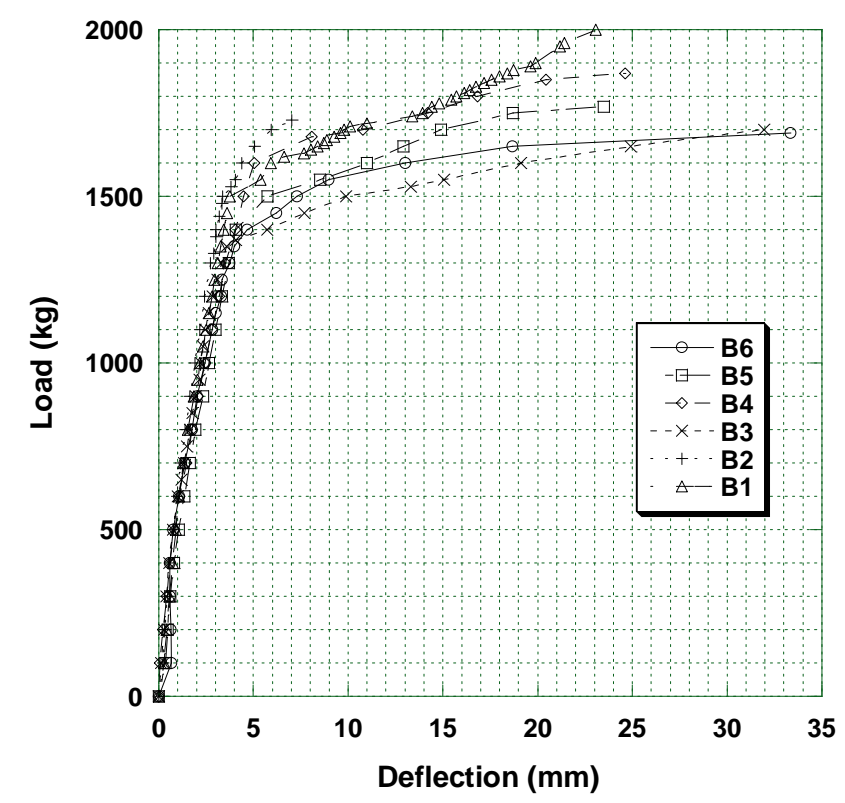

Fig. (11). Load and deflection for series I and II tests.

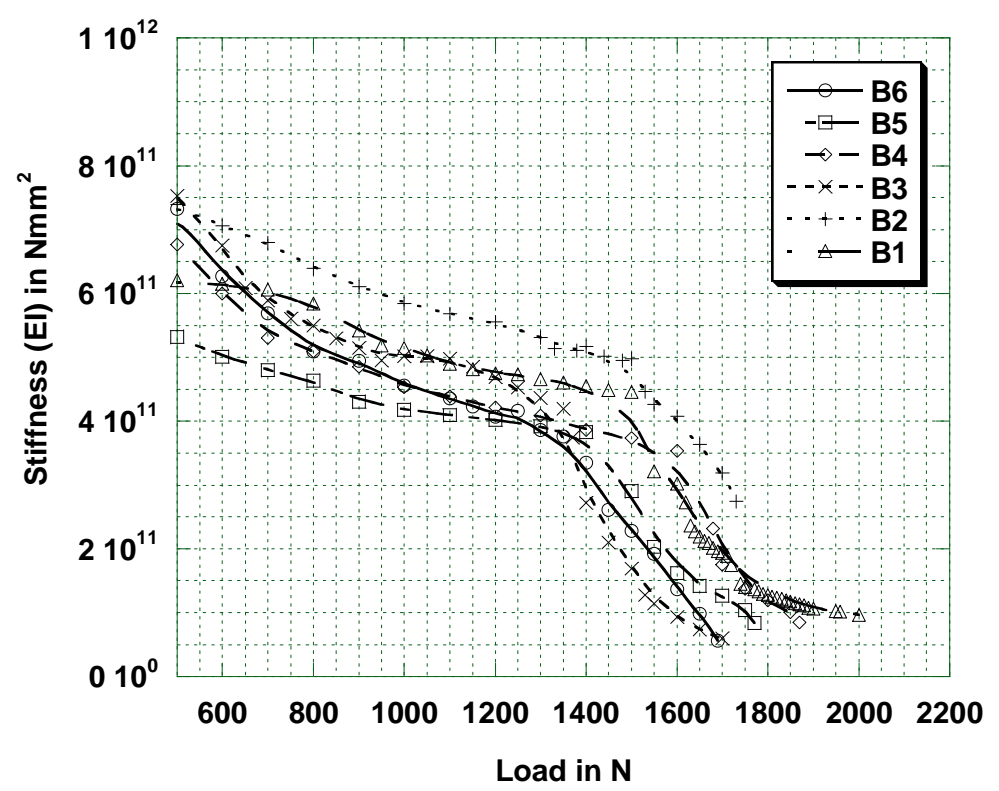

Fig. (12). Stiffnes degradation curve for series I and II tests. 
The deflection of all beams at failure is given in Table 8. This table shows that at failure load the beams deflect significantly varies from $1.8 \%$ to $2.6 \%$ of their span. If the allowable deflection of the beam is taken as $\mathrm{L} / 350 \mathrm{or} 0.3 \%$ of span, than the deflection of GPC beam at failure varied between 6 to 8 times of the allowable deflection. The highest deflection at failure was recorded for B3 for series I test and for B6 for series II test. Both B3 and B6 have the lowest ultimate load. The ductility factor $\mu$ for the beams is also given in Table 8. All the beams have the ductility factor greater than 4.

Table 8. Deflection at failure load and at yield of tension steel.

\begin{tabular}{|c|c|c|c|c|}
\hline Sample & Deflection at failure $(\Delta u) ~ m m$ & Deflection at yield $(\Delta y) \mathrm{mm}$ & $\mu=\Delta \mathbf{u} / \Delta \mathbf{y}$ & $\Delta \mathbf{u} / \mathbf{L}^{*}$ \\
\hline B1 & $17.170 * *$ & 4.66 & NA & $1.3 \%$ \\
\hline B2 & $7.023 * *$ & 5.05 & NA & $0.5 \%$ \\
\hline B3 & 31.973 & 7.68 & 4.16 & $2.5 \%$ \\
\hline B4 & 24.640 & 5.05 & 4.88 & $1.9 \%$ \\
\hline B5 & 23.480 & 5.75 & 4.08 & $1.8 \%$ \\
\hline B6 & 33.343 & 4.66 & 7.16 & $2.6 \%$ \\
\hline
\end{tabular}

$* \mathrm{~L}=$ beam span $=1300 \mathrm{~mm}$

**deflection recorded not at failure load

\subsection{Cracking and Ultimate Load}

Fig. (13) summarizes cracking and ultimate load of series I and II tests. Cracking load is defined as load at first crack formation, whereas ultimate load is defined as load at failure. P design in this figure is defined as the ultimate load of GCB determined using available formulae for normal concrete. For series I test, first crack did not form in the beams until load has reached $70 \%$ of ultimate load. On the contrary, for series II first crack has already formed when applied load reached $30 \%$ of ultimate load. Based on the average value of three beams, the average cracking load of series I was $275 \%$ higher than the cracking load of series II test. This highest cracking loads correspond to the results of splitting tensile tests, where the proportion of tensile strength to the compressive strength is about twice that of normal concrete. Reddy et al. [20] found similar trend in their experimental program, in which twelve concrete geopolymer beams and six ordinary concrete beams with dimension of $6 \times 6 \times 21$ inch were accelerated corrosion test in natural sea water. After corrosion test, these beams were flexural load tested under three-point bending test based on ASTM C-78-09 [21]. The bending test showed that the average flexural strength of geopolymer concrete beam was $240 \%$ higher than that of ordinary concrete beam. Fig. (13) also shows that the average ultimate load of series I test was also higher than that of series II test. Based on the average value of three beams, the ultimate load of series I was $15 \%$ higher than the ultimate load of series II test.

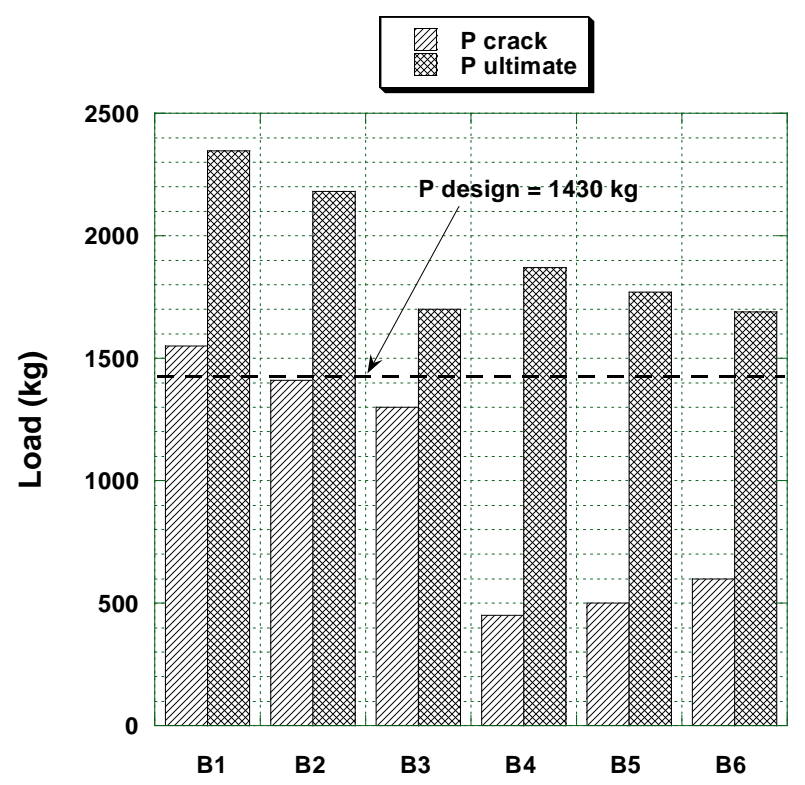

Fig. (13). Cracking and ultimate load of series I and II tests. 


\section{CONCLUSION}

This paper presents the study of flexural strength of geopolymer concrete beam using high calcium content fly ash in marine environment, without high heat curing. From test results after 28 days of curing, it can be concluded that sea water has almost no effect on compressive and splitting tensile strength of fly ash-based geopolymer concrete. However, the ratio of splitting and compressive for geopolymer concrete cylinder is about $44 \%$, almost double than that of normal concrete. Further, the cracking load for beams cured in sea water at splashing zone (series I) is $275 \%$ higher than the cracking load of beams cured in room temperature (series II). Observation during loading test indicates that the crack pattern for series I and II tests was very similar.

\section{CONFLICT OF INTEREST}

The authors confirm that this article content has no conflict of interest.

\section{ACKNOWLEDGEMENTS}

The author thank the Ministry of Research, Technology and Higher Education of the Republic of Indonesia for funding this research.

\section{REFERENCES}

[1] P. Duxson, A. Fernandez-Jimenez, J.L. Provis, G.C. Lukey, A. Palomo, and J.S. Deventer, "Geopolymer technology: the current state of the art", J. Mater. Sci., vol. 42, no. 9, pp. 2917-2933, 2007.

[http://dx.doi.org/10.1007/s10853-006-0637-z]

[2] A. Kusbiantoro, N. Rahman, S.C. Chin, and R. Bayu Aji, "Effect of poly (ethylene-co-vinyl acetate) as a self-healing agent in geopolymer exposed to various curing temperatures", Mat. Sci. Forum, vol. 841, pp. 16-20, 2016. [http://dx.doi.org/10.4028/www.scientific.net/MSF.841.16]

[3] A.K. Valliappan, R.R. Suppiah, S. Irawan, and R. Bayuaji, "Development of new green cement for oil wells", Mat. Sci. Forum, vol. 841, pp. 148-156, 2016.

[http://dx.doi.org/10.4028/www.scientific.net/MSF.841.148]

[4] L.Y. Dwijayanti, J.J. Ekaputri, and R. Bayuaji, "Lightweight geopolymer binder with abaca fiber in different curing", Mat. Sci. Forum, vol. 841, pp. 140-147, 2016.

[5] R. Bayuaji, M.F. Nuruddin, S. Francis, J. Ekaputri, S. Junaedi, and H. Fansuri, "Mechanical Properties of MIRHA-Fly Ash Geopolymer Concrete", Mat. Sci. Forum, vol. 803, pp. 49-57, 2015.

[http://dx.doi.org/10.4028/www.scientific.net/MSF.803.49]

[6] R. Bayuaji, T.R. Biyanto, and S. Irawan, "Design of cement plant waste heat recovery generation", Power Eng. Conf. (AUPEC), pp. 1-5, 2015 .

[http://dx.doi.org/10.1109/AUPEC.2015.7324816]

[7] J.J. Ekaputri, M. Bahrul Ulum, B. Ridho, T.E. Susanto, and M.M. Al Bakri Abdullah, "A comprehensive characterization and determination of fly ashes in indonesia using different methods", Appl. Mech. Mat., vol. 754-755, pp. 320-325, 2015.

[http://dx.doi.org/10.4028/www.scientific.net/AMM.754-755.320]

[8] W. Supriadi, R. Bayuaji, R. Burhan, and H. Fansuri, "The effect of Pb 2+ and Cd 2+ addition to mechanical properties of fly ash geopolymer paste", Mat. Sci. Forum, vol. 841, pp. 178-185, 2016.

[9] H. Fansuri, A. Fatmawati, W.P. Utomo, W. Supriadi, and R. Bayuaji, "Cd 2+ and Cr 3+ cation immobilization by using geopolymer based on PT. IPMOMI fly ash", Mat. Sci. Forum, vol. 841, pp. 186-192, 2016.

[10] S.E. Wallah, and B.V. Rangan, Low-Calcium Fly Ash-Based Geopolymer Concrete: Long-Term Properties., Faculty of Engineering Curtin University of Technology: Perth, Australia, 2006.

[11] X. Guo, H. Shi, and W.A. Dick, "Compressive strength and microstructural characteristic of class C fly ash geopolymer", Cement Concr. Compos., vol. 32, pp. 142-147, 2010.

[http://dx.doi.org/10.1016/j.cemconcomp.2009.11.003]

[12] M.S. Darmawan, R. Bayuaji, B. Wibowo, N.A. Husin, S. Subekti, and J.J. Ekaputri, "The influence of chloride environment on compressive strength of geopolymer concrete with fly ash using taguchi approach", Appl. Mech. Mat., vol. 754-755, pp. 400-405, 2015. [http://dx.doi.org/10.4028/www.scientific.net/AMM.754-755.400]

[13] K. Erdoğdu, and P. Türker, "Effects of fly ash particle size on strength of Portland cement fly ash mortars", Cement Concr. Res., vol. 28, pp. 1217-1222, 1998. [http://dx.doi.org/10.1016/S0008-8846(98)00116-1]

[14] N. Koukouzas, J. Hämäläinen, D. Papanikolaou, A. Tourunen, and T. Jäntti, "Mineralogical and elemental composition of fly ash from pilot scale fluidised bed combustion of lignite, bituminous coal, wood chips and their blends", Fuel, vol. 86, pp. $2186-2193,2007$. [http://dx.doi.org/10.1016/j.fuel.2007.03.036] 
[15] K. Wesche, Fly ash in concrete: properties and performance. (Rilem Report 7), CRC Press: USA, 2004.

[16] J.J. Ekaputri, "Geopolymer grout material", Mat. Sci. Forum, vol. 841, pp. 40-47, 2016.

[17] P. Chindaprasirt, and W. Chalee, "Effect of sodium hydroxide concentration on chloride penetration and steel corrosion of fly ash-based geopolymer concrete under marine site", Construct. Build. Mater., vol. 63, pp. 303-310, 2014. [http://dx.doi.org/10.1016/j.conbuildmat.2014.04.010]

[18] G.S. Ryu, Y.B. Lee, K.T. Koh, and Y.S. Chung, "The mechanical properties of fly ash-based geopolymer concrete with alkaline activators", Construct. Build. Mater., vol. 47, pp. 409-418, 2013. [http://dx.doi.org/10.1016/j.conbuildmat.2013.05.069]

[19] J. Temuujin, A. van Riessen, and R. Williams, "Influence of calcium compounds on the mechanical properties of fly ash geopolymer pastes", J. Hazard. Mater., vol. 167, no. 1-3, pp. 82-88, 2009. [http://dx.doi.org/10.1016/j.jhazmat.2008.12.121] [PMID: 19201089]

[20] D.V. Reddy, J-B. Edouard, and K. Sobhan, "Durability of fly ash-based geopolymer structural concrete in the marine environment", J. Mater. Civ. Eng., vol. 25, pp. 781-787, 2013.

[http://dx.doi.org/10.1061/(ASCE)MT.1943-5533.0000632]

[21] ASTM-C78-09, "Standard Test Method for Flexural Strength of Concrete (Using Simple Beam with Third-Point Loading)", ASTM International, West Conshohocken, PA 2009.

C) Bayuaji et al.; Licensee Bentham Open

This is an open access article licensed under the terms of the Creative Commons Attribution-Non-Commercial 4.0 International Public License (CC BY-NC 4.0) (https://creativecommons.org/licenses/by-nc/4.0/legalcode), which permits unrestricted, non-commercial use, distribution and reproduction in any medium, provided the work is properly cited. 